\title{
Pandemi Penyakit dalam Lintasan Sejarah dan Dampaknya Terhadap Gejolak Sosial Politik
}

\author{
Rusdi \\ rusdi64@fis.unp.ac.id \\ Universitas Negeri Padang
}

\begin{abstract}
Outbreak history is of equal length, or even longer, than human information. Various studies have shown that infectious diseases have afflicted humans since prehistoric times. However, because of their simple, nomadic, hunting and gathering style of life and living in small, successful groups, disease does not become a pandemic because of the chance of disease transmission from one group to a smaller group. Turning into humans has found a new mode of production for farming. Because humans settle and build communities in villages and cities, they must focus on infectious diseases on a larger scale. In the history of human civilization, the influence of disease on death would have been significant when humans began an agrarian civilization. In addition to causing death, the pandemic also created social political turmoil and even toppled a regime. Infectious diseases appear in every age, and political upheaval almost always occurs. This paper aims to analyze the disease pandemic in the course of history which has an impact on social political turmoil.
\end{abstract}

Keywords: Pandemic, historical trajectory, change, social politics

\begin{abstract}
Abstrak
Riwayat wabah sama panjangnya, atau bahkan lebih panjang, dari pada riwayat hidup manusia. Berbagai penelitian menunjukkan bahwa penyakit menular telah menimpa manusia sejak masa prasejarah. Namun, karena corak kehidupan mereka yang sederhana, nomaden, berburu dan meramu serta hidup dalam kelompok kecil yang terisolasi, penyakit tidak sampai menjadi pandemi karena kesempatan transmisi penyakit dari satu kelompok ke kelompok lainnya sangatlah kecil. Situasi itu berubah ketika manusia menemukan modus produksi baru yakni bercocok tanam. Sejak manusia menetap dan membangun komunitas di desa dan (terutama) kota, mereka harus berurusan dengan penyakit menular dalam skala yang lebih besar. Dalam sejarah peradaban manusia, pengaruh penyakit terhadap kematian kiranya menjadi signifikan tatkala manusia mulai memasuki peradaban agraris. Selain menyebabkan kematian, pandemi ternyata juga menciptakan gejolak sosial politik bahkan sampai menumbangkan sebuah rezim. Penyakit menular muncul di setiap zaman, dan hampir selalu mengakibatkan pergolakan politik. Tulisan ini bertujuan untuk menganalisis pandemi penyakit dalam lintasan sejarah yang berdampak terhadap gejolak sosial politik.
\end{abstract}

Kata Kunci: Pandemi, lintasan sejarah, dampak, sosial politik. 
DIAKRONIKA 20 (1) 2020

ISSN: 1411-1764 (Print) | 2620-9446 (Online)

\section{Pendahuluan}

Dalam sejarah peradaban manusia, pengaruh penyakit terhadap kematian kiranya menjadi signifikan tatkala manusia mulai memasuki peradaban agraris. Pada masa berburu dan meramu, kematiann lebih banyak disebabkan oleh kurangnya nutrisi, intaficide atau pembunuhan bayi, dan geronticide atau pembunuhan orang usia tua (Weeks, J, 2008). Namun, setelah memasuki revolusi agraris, faktor yang menyebabkan kematian berubah. Meskipun manusia mempunyai nutrisi yang lebih baik, tapi kontak yang semakin dekat satu sama lain, baik sesama manusia maupun manusia dengan hewan, telah menjadikan penyakit semakin mudah menular dan menjadi ancaman bagi kehidupan (Weeks, J, 2008); (Tahrus, 2020).

Sejarawan terkemuka Universitas Chicago bernama William McNeill menulis sebuah buku yang berjudul Plagues and Peoples pada 1976. Buku itu adalah ramalan yang mengerikan untuk masa mendatang. McNeill mengatakan bahwa sejak obatobatan abad ke-20 telah secara efektif mengendalikan sejumlah penyakit mematikan (cacar dan polio), para pemimpin dunia justru menjadi puas diri. Namun, lonjakan populasi dunia akhirnya menciptakan sebuah "pergolakan ekologis yang luar biasa". McNeill memperingatkan para pembaca bahwa penyakit menular akan selalu ada dan bahkan menjadi hal yang fundamental dari catatan sejarah umat manusia. Dia bahkan menunjuk kemungkinan akan pandemi berikutnya yakni bentuk mutasi dari virus influenza. McNeill mencatat bahwa virus influenza tidak hanya sangat menular, tetapi juga tidak stabil dan mengalami rincian struktur ilmiah yang berubah pada frekuensi intervalnya, mencegah manusia memperoleh kekebalan jangka panjang, seperti yang ditulis pada halaman History News Network.

Penyakit menular muncul di setiap zaman, dan hampir selalu mengakibatkan pergolakan politik. Untuk zaman ini, penyakit itu telah datang. Pada 1377 Masehi, sejarawan Arab Ibnu Khaldun menerbitkan buku Muqaddimah, yang masih digunakan untuk studi sejarah dunia sampai saat ini. Ibnu Khaldun menyimpulkan ada hukum universal dinamika sosial. Kontribusi Muqaddimah-nya yang paling orisinal adalah konsep asabiyyah, atau solidaritas kelompok. Bagi Ibnu Khaldun, pola dasar sejarah manusia adalah siklus dinasti, naik turunnya peradaban, dan asabiyyah (rasa tujuan bersama dan kohesi sosial) adalah sumber kekuatan yang memungkinkan aksi kolektif selama fase pertumbuhan sebuah dinasti atau peradaban. Namun, pada akhirnya, kesuksesan dan kemakmuran berperan dalam merusak rasa solidaritas yang memungkinkan satu kelompok untuk naik ke kekuasaan. Dengan demikian, peradaban terkorupsi dari dalam.

Ibnu Khaldun mengembangkan teori perintis tentang perubahan historis, menggabungkan ranah sosial dan politik dengan dinamika ekonomi dan demografi. 
Yang luar biasa, sejarawan Arab ini meramalkan bagaimana penyakit menular dapat terintegrasi ke dalamnya. Dia telah hidup melalui Black Death, dengan bencana-bencana biologis terburuk dalam sejarah manusia. Bagi Ibnu Khaldun, wabah penyakit merupakan komponen integral dari keruntuhan peradaban. Wabah bukan hanya takdir Tuhan atau fenomena acak dari alam. Mereka adalah fenomena yang rentan yang memiliki penjelasan rasional. Epidemi mungkin merupakan hasil dari pertumbuhan populasi itu sendiri. Peradaban yang kuat dengan pemerintahan yang baik akan memfasilitasi peningkatan populasi. Namun secara paradoksal, peningkatan demografis akan memicu penyakit epidemi yang mematikan dan disintegrasi sosial.

Dalam merumuskan epidemiogolical trantition, Omran membagi sejarah manusia menjadi tiga era, yaitu 1) era wabah dan kelaparan, 2) era surutnya pandemi dan 3) era degeneratif dan penyakit buatan manusia (man-made disease) (Kahn, 2006). Masingmasing dari era tersebut memiliki pola mortalitas dan harapan hidup yang berbedabeda. Era wabah dan kelaparan ditandai oleh tingginya tingkat mortalitas pada usia anak-anak, dan balita, era surutnya pandemi ditandai dengan mulai naiknya tingkat harapan hidup dan pertumbuhan penduduk yang berkelanjutan, sedangkan era degenaratif dan penyakit buatan manusia ditandai dengan semakin tingginya angka harapan hidup hingga usia tertua (older ages) (Kahn, 2006). Peristiwa pandemi sudah tercatat dalam sejarah sejak tahun 430 BC sampai sekarang dan berpengaruh terhadap umat manusia, membuat gejolak sosial politik selain menciptakan kematian. Makalah ini bertujuan untuk menganalisis tentang Pandemi Penyakit Dalam Lintasan Sejarah dan Dampaknya Terhadap Gejolak Sosial Politik.

\section{Pembahasan}

\section{Pandemi Penyakit Dalam Lintasan Sejarah}

Riwayat wabah sama panjangnya, atau bahkan lebih panjang, dari pada riwayat manusia. Berbagai penelitian menunjukkan bahwa penyakit menular telah menimpa manusia sejak masa prasejarah. Namun, karena corak kehidupan mereka yang sederhana, nomaden, berburu dan meramu serta hidup dalam kelompok kecil yang terisolasi, penyakit tidak sampai menjadi pandemi karena kesempatan transmisi penyakit dari satu kelompok ke kelompok lainnya sangatlah kecil. Situasi itu berubah ketika manusia menemukan modus produksi baru yakni bercocok tanam. Sejak manusia menetap dan membangun komunitas di desa dan (terutama) kota, mereka harus berurusan dengan penyakit menular dalam skala yang lebih besar. Kemudian, pembangunan imperium memfasilitasi penyebaran berbagai penyakit di sepanjang rute perniagaan dan peperangan. Sepanjang sejarah umat manusia telah ada beberapa pandemi penyakit diantaranya seperti dijelaskan berikut ini. 
Pandemi Peloponnesia, merupakan pandemi paling awal tercatat pada masa Perang Peloponnesia (430 SM). Penyakit itu diduga datang dari Ethiopia dan mewabah di Athena, tepat ketika pasukan Sparta mengepung. Dua pertiga dari populasi meninggal. Dalam History of Peloponnesian War (431 SM), Thucydides menulis, "Wabah yang begitu parah dan mematikan, para dokter yang tidak peduli dengannya bukan saja tidak berdaya, tetapi mereka justru yang paling cepat meninggal karena paling banyak berhubungan dengan orang sakit. Di Athena yang penuh sesak, penyakit ini menewaskan sekitar 25\% populasi." Pandemi ini berdampak serius terhadap masyarakat Athena, bahkan menurunkan kepatuhan terhadap aturan dan keyakinan religius mereka (Ridho, 2020). Wabah pandemi berikutnya adalah Wabah Justinian, yang menular tahun 527-565M pada masa Kekaisaran Justinian di Konstantinopel. Wabah ini diperkirakan telah menewaskan hampir separoh penduduk Eropa. Wabah ini berasal dari China, timur laut India lalu ke danau besar Afrika yang ditularkan oleh tikus hitam (Mardatila, 2020). Untuk mencegah wabah tersebut pada saat itu yang dilakukan hanya menghindari yang sakit. Besar keyakinan pada waktu itu pandemi berakhir karena orang yang terinfeksi dan masih hidup menghasilkan imunitas (Nursastri, 2020).

Pada tahun 1347-1351 muncul pandemi Black death, penyakit ini diperkirakan telah merenggut nyawa dua per tiga populasi Eropa. Orang yang terkena penyakit ini kulitnya akan menghitam karena pendarahan. Penularan penyakit ini melalui sejenis binatang kutu atau tikus hitam. Namun sejarah mencatat bahwa para ilmuwan berkeyakinan bahwa Black Death adalah wabah pes, yang disebabkan oleh bakteri Yersinia (Mardatila, 2020). Pada saat itu, pemerintah kota pelabuhan Ragusa di Italia melakukan karantina terhadap para pelayar untuk membuktikan bahwa mereka tidak membawa penyakit. Pada awalnya, para pelayar ditahan di kapal mereka selama 30 hari. Hukum Venesia menamai kondisi ini sebagai trentino. Kemudian, masa isolasi bertambah menjadi 40 hari yang dikenal sebagai quarantine, asal mula kata quarantine dan karantina.

Pandemi berikutnya adalah cacar, wabah yang muncul takkala bangsa Eropa mendatangi benua Amerika pada tahun 1492. Penyakit ini menyebabkan kematian lebih kurang 90 persen penduduk Amerika periode itu. Wabah ini secara tidak langsung telah mendorong bangsa Eropa untuk mendatangi dan menjajah benua Amerika.Tidak jelas dari mana bermula wabah cacar ini, namun para ahli memperkirakan penyakit ini berawal dari Kekaisaran Mesir abad ke-3 SM, dengan bukti ruam yang terdapat pada mumi. Wabah yang mirip dengan cacar juga ditemukan di Cina abad ke-4 M, penyakit ini sudah mulai diberantas sejak tahun 1979 dengan diketemukannnya vaksin (Mardatila, 2020). Selama berabad-abad, cacar air merupakan penyakit endemic di Eropa, Asia, dan negara-negara Arab. Penyakit ini menewaskan 3 dari 10 orang yang 
Rusdi

Pandemi Penyakit Dalam Lintasan Sejarah dan Dampaknya Terhadap Gejolak Sosial Politik

terinfeksi, sisanya mengalami bekas luka yang cukup parah. Sekelompok orang yang membawa penyakit ini dari masa lampau ke dunia modern adalah para penjelajah Eropa. Populasi yang kini menempati wilayah Meksiko dan AS memiliki nol imunitas terhadap cacar air. Dengan munculnya para penjelajah Eropa, angka kematian di dua wilayah tersebut mencapai puluhan juta orang. Beberapa abad kemudian, cacar merupakan virus epidemi pertama yang memiliki vaksin. Butuh waktu setidaknya dua abad kemudian, yaitu 1980-an, World Health Organization mengumumkan cacar air akhirnya kandas dari muka bumi (Nursastri, 2020). Kolera, merupakan pandemi yang muncul sekitar tahun 1961 yang diperkirakan berasal dari distrik Jessore India. Badan Kesehatan Dunia WHO memberi nama "pandemi yang terlupakan". Penyakit ini telah menjangkiti hampir empat juta manusia setiap tahunnya dan menyebabkan kematian 21.000-143.000 orang tiap tahun. Penyebab penyakit ini adalah makanan atau air yang terkontaminasi oleh bakteri, wabah ini sangat rentan bagi negara yang berpenduduk miskin. Sebelumnya yakni sekitar tahun 1852-1860 wabah kolera dengan cepat telah menyebar keseluruh Asia, Eropa, Amerika dan Afrika yang menyebabkan kematian sekitar 1 juta orang.

Pada awal abad ke-19, penyakit kolera menguasai Inggris, menewaskan puluhan ribu orang. Adalah John Snow, dokter yang menyadari bahwa penyakit tersebut berasal dari air minum. Snow kemudian meyakinkan pemerintah setempat untuk mengganti handle di sumber air Broad Street, kemudian infeksi kolera pun berkurang seketika. Hal yang dilakukan Snow menjadi acuan banyak pihak untuk memperbaiki sanitasi, dan menjaga kebersihan air minum dari kontaminasi bakteri. Saat ini, kolera telah tereliminasi dari negara-negara maju. Namun di negara-negara dunia ketiga, kolera masih menjadi momok karena terbatasnya akses air bersih (Nursastri, 2020) Pandemi berbahaya yang lain adalah Flu Spanyol, wabah ini dengan mudah menyebar keseluruh dunia pada tahun 1918-1919, penyebabnya adalah virus H1N1 yang kemungkinan berasal dari burung. Diperkirakan 500 juta orang terjangkit penyakit ini dan sekitar 50 juta menyebabkan kematian diseluruh dunia.

Ada dua versi yang menyebutkan asal kemunculan virus Flu Spanyol. Perkiraan pertama, virus ini mulai mewabah di kompleks militer Fort Riley, Amerika Serikat pada Maret 1918. Virus ini lalu menyebar ke Eropa ketika Amerika Serikat mengirim tentara ke medan Perang Dunia I. Perkiraan lain menyebutkan, wabah flu Spanyol bermula di Swedia atau Rusia dan lalu menyebar ke Cina, Jepang, hingga Asia Tenggara. Spanish Flu menyebabkan kematian sekitar 40-50 juta orang hanya dalam kurun waktu satu tahun saja. Pada saat itu, tidak ada obat atau vaksin yang efektif untuk mengobati jenis flu yang mematikan ini. Warga diperintahkan untuk mengenakan masker; sekolah, teater dan bisnis ditutup; mayat-mayat ditumpuk di kamar mayat sementara sebelum virus berakhir pada musim panas tahun 1919. Virus ini menghilang secara misterius 
karena dibayangi oleh kematian pada Perang Dunia I dan tertutupi oleh pemadaman berita dan pencatatan yang buruk. Satu abad setelahnya ia kembali dan dikenal sebagai Flu Babi meski tidak menyebabkan jumlah kematian seperti pada saat kemunculan pertamanya (Ridho, 2020).

Pada masa kolonial Belanda, Indonesia juga terdampak oleh wabah tersebut, laporan tertulis dari pemerintah kolonial menunjukkan bahwa penyakit tersebut juga mewabah di Hindia Belanda. Pandemi yang cukup berdampak adalah pandemi Influenza 1918 atau Flu Spanyol, termasuk wabah terganas karena menyebabkan kematian jutaan manusia, diperkirakan wabah ini menewaskan lebih kurang 40 juta orang. (Priyanto Wibowo, dkk, 2008). SARS atau Severe Acute Respiratory Syndrome, adalah satu pandemi yang muncul pada tahun 2003 yang berasal dari Cina dan menyebar ke 26 negara menjangkiti sekitar 8.000 orang menyebabkan kematian 774 orang. Pandemi baru muncul lagi di AS pada tahun 2009 yang dikenal sebagai "flu babi", pandemi ini telah menginfeksi lebih kurang 60 juta warga AS dan menibulkan kematian global sebanyak 575.400. Pandemi ini menginfeksi terutama anak kecil dan orang dewasa paroh baya, sedangkan orang dewasa yang lebih tua memiliki kekebalan tubuh, pandemi ini berakhir pada bulan Agustus 2010. Pandemi Ebola, adalah wabah yang muncul di Guinea Afrika tahun 2014, dan menular ke negara-negara di Afrika Barat seperti Liberia dan Sierra Leone. Wabah ini talah menginfeksi lebih kurang 28.600 orang dan menyebabkan kematian sekitar 11.325 orang.

Wabah berikut ini adalah Human Immunodeficiency Virus (HIV) dan Immunodeficiency Syndrome (AIDS) yang muncul di AS sekitar tahun 1980-an, penyebab wabah ini diperkirakan berasal dari virus simpanse dari Afrika. Menurut data tahun 2006 virus tersebut merupakan pandemi dengan 65 juta orang lebih terjangkit dan menyebabkan kematian 25 juta secara global (Mardatila, 2020). Itulah beberapa wabah penyakit yang memiliki dampak cukup besar dalam sejarah, mulai dari Pandemi Peloponnesi, Wabah Justinian, Black death, Cacar, Kolera, Flu Spanyol, SARS, Flu Babi, Ebola, HIV/AIDS sampai yang sekarang masih berjangkit yakni virus Corona. Ada pandemi yang berakhir karena orang yang terinfeksi dan masih hidup menghasilkan imunitas seperti Wabah Justinian. Kemudian, ada juga pandemi berakhir dengan cara isolasi dan karantina. Penyakit cacar dapat diberantas sejak tahun 1979 dengan ditemukannya vaksin. Ada pula virus yang menghilang secara misterius karena dibayangi oleh kematian pada Perang Dunia I dan tertutupi oleh pemadaman berita dan pencatatan yang buruk, seperti Flu Spanyol. 
Rusdi

Pandemi Penyakit Dalam Lintasan Sejarah dan Dampaknya Terhadap Gejolak Sosial Politik

\section{Dampak Penyakit Pandemik Memicu Gejolak Sosial Politik}

Fakta sejarah menunjukkan bahwa wabah penyakit selain menyebkan kematian juga menimbulkan gejolak sosial politik. Pandemi corona yang masih berlangsung sampai sekarang telah menyebabkan kemerosotan ekonomi di berbagai negara di dunia termasuk di Indonesia. Pemerintah Indonesia telah mengeluarkan anggaran lebih dari 600 triliun untuk penanganan wabah tersebut. Arwin Juli Rakhmadi Butar-Butar, menjelaskan bahwa informasi sejumlah naskah-naskah manuskrip yang membahas tentang wabah penyakit menular, khususnya yang dikenal dalam sejarah Islam dengan Tha'un. Melalui informasi naskah-naskah (manuskrip) yang pernah ditulis oleh para ulama dan dokter Muslim ini, tampak bahwa fenomena wabah penyakit menular (pandemi) sejatinya telah ada dan berulang kali terjadi sepanjang sejarah umat manusia. Selain itu, berbagai literatur (manuskrip) ini juga memberi pesan dan kearifan bahwa setiap fenomena wabah senantiasa terkait dengan aspek sosial, medis, dan syariat. (Arwin Juli Rakhmadi Butar-Butar, 2020).

Pada pertengahan abad ke-6, di Mesir muncul wabah Justinian yang menyebar melalui Palestina dan Kekaisaran Bizantium, dan kemudian ke seluruh Mediterania. Wabah itu menyebabkan rencana Kaisar Justinia untuk menyatukan Kekaisaran Romawi gagal dan menyebabkan kekacauan ekonomi besar-besaran. Hal ini juga menciptakan suasana apokaliptik yang mendorong penyebaran agama Kristen dan kejatuhan imperium Romawi. Wabah ini menewaskan sekitar 30-50 juta orang, atau sekitar $26 \%$ dari populasi dunia. Ini juga diyakini sebagai awal mula kemunculan penyakit pes yang dibawa oleh tikus dan disebarkan oleh kutu yang menyebabkan wabah Black Death berabad-abad setelahnya (Ridho, 2020). Pandemi ini telah menyebabkan aktivitas perekonomian terhenti, dan melemahkan kekuaasaan Kekaisaran Binzantium, serta terancam direbut oleh peradaban lainnya. Usaha dari Justianus untuk menyatukan Romawi Barat dan Romawi Timur terhenti, dengan terjadinya wabah ini dan Kaisar tidak dapat mengatasinya, maka ia divonis sehingga mengakiri pemerintahannya.

Episode wabah nampaknya berkontribusi pada melemahnya Kekaisaran Bizantium dalam bidang politik dan ekonomi. Ketika penyakit menyebar ke seluruh dunia Mediterania, kemampuan kekaisaran untuk melawan musuh-musuhnya melemah. Sektor pertanian hancur dan perdagangan terganggu. Diperkirakan setiap harinya terjadi 5000 kematian di ibu kota (Mardatila, 2020). Pada 1347, wabah kembali menghampiri Eropa. Ia masuk melalui kota Kaffa (saat ini Feodosia, Ukraina) di Krimea, yang dibawa oleh tentara Kekaisaran Mongol pada masa pengepungan. Para pedagang yang melarikan diri tanpa sadar membawanya kembali ke Italia. Dari sana, wabah ini menyebar ke Prancis, Spanyol dan Inggris. Kemudian sampai ke Norwegia dan seluruh Eropa, bahkan sampai ke Moskow. Puluhan juta orang tertimpa penyakit, 
tubuh mereka menyerah pada penyakit dengan cara yang berbeda. Beberapa orang menunjukan bengkak di leher, ketiak, dan paha mereka; beberapa menunjukkan daging yang menghitam karena pendarahan di bawah kulit; beberapa batuk darah karena peradangan di tenggorokan dan paru-paru mereka. Tetapi mereka semua mengalami satu hal yang sama: demam, kelelahan, dan bau busuk yang menguap dari tubuh. Wabah yang dikenal sebagai Black Death ini menyebabkan kematian pada sepertiga populasi Eropa atau sekitar 200 juta orang. Ia bahkan menyebabkan Inggris dan Prancis, yang saat itu berperang, untuk melakukan gencatan senjata. Hal ini juga dianggap menjadi awal dari keruntuhan sistem feodal Inggris karena berdampak pada demografi petani saat itu. Teori paling populer mengatakan wabah Black Death berakhir melalui penerapan karantina. Yang tidak terinfeksi biasanya akan tetap tinggal di rumah dan hanya pergi jika diperlukan, sementara mereka yang mampu melakukannya akan meninggalkan daerah yang lebih padat penduduknya dan hidup dalam area isolasi. Perbaikan dalam kebersihan pribadi juga dianggap sudah mulai terjadi selama pandemi. Alih-alih mengubur jenazah yang terinfeksi wabah, praktik kremasi dilakukan untuk memastikan wabah tidak lagi menular (Ridho, 2020).

Pada abad ke-16, Small Pox atau cacar mewabah. Meski sudah ditemukan sejak awal peradaban manusia, wabah ini hampir melibas habis pribumi Amerika selepas kedatangan orang Spanyol di Karibia. Hal ini terus berlanjut hingga seorang dokter asal Inggris, Edward Jenner, memformulasikan vaksin pada tahun 1976. Kekaisaran Aztec adalah korban dari wabah ini, ia runtuh pada tahun 1520 ketika banyak rakyatnya terinfeksi cacar oleh para budak Afrika. Flu Kuning, yang menimpa AS tahun 1690-an dan mewabah tahun 1793 yang menyebabkan kematian lebih dari 500 orang dan sampai di Haiti tahun 1880-an. Dampak utama dari wabah ini adalah terjadinya kemerdekaan Haiti 14 Agustus 1804. Pasukan Haiti yang dipimpin oleh Toussaint L'Ouverture, berhasil mengalahkan pasukan Napoleon Bonaparte yang terkena flu kuning sedangkan pasukan Haiti atau pasukan budak kulit hitam mempunyai kekebalan tubuh yang lebih kuat.

Wabah Human Immunodeficiency Virus (HIV), telah menginfeksi warga Haiti dan menyebabkan kemerosotan ekonomi. Devisa utama Haiti adalah dari sektor pariwisata yang mayoritas berasal dari Amerika Serikat, sementara akibat wabah HIV, pemerintah Amerika Serikat memberlakukan larangan kunjungan ke Haiti. Hal ini menyebabkan kekacauan Ekonomi Haiti. Pecahlah Revolusi sosial yang akhirnya menuntut Duvalier mundur. Pada awal 1986 pemimpin Haiti tersebut lengser dari jabatannya. Wabah kolera, yang berlangsung lama telah berdampak sosial dan politik pada beberapa negara dan peristiwa. Perang Franco-Prussian misalnya termasuk yang terdampak kolera. Ketika terjadi perang di Eropa tahun 1871 pandemi ini sedang mewabah. Hal ini 
menyebabkan demobilisasi pasukan di Perancis karena terserang kolera dan mengakhiri perang ini. Pandemi ini juga menyebabkan terjadinya revolusi Paris pada 1832. Karena pada waktu itu Paris termasuk kota yang kotor dan mudahnya wabah kolera menular serta menyebabkan 20 ribu orang meninggal. Serta ada issu bahwa orang yang menderita kolera sengaja dibunuh. Hal ini menumbulkan gerakan perlawanan Kelompok Société des droits de l'homme yang menghimpun massa hingga akhirnya pecah revolusi, dan menciptakan pergolakan dengan Garda Nasional (Ridhoi, 2020).

Terkait wabah yang berkembang di Nusantara, Dr. Gani Ahmad Jaelani, DEA, mengutip bahwa penyakit yang merebak saat itu antara lain disentri, beri-beri, kolera, dan kinderpox (kemungkinan sejenis campak). Bontius, yang juga seorang naturalis itu, mengumpulkan informasi mengenai tumbuh-tumbuhan yang digunakan sebagai obatobatan untuk penyakit-penyakit yang berkembang saat itu. Gani juga menceritakan tentang wabah malaria yang berkembang pada abad 18. "Banyak yang bilang bahwa VOC runtuh karena korup," tutur Gani. "Mungkin ada satu penyebab (keruntuhan VOC) lagi yaitu malaria abad 18", lanjutnya. Dikatakan Gani bahwa Batavia merupakan kota yang tidak sehat. Pembangunan kanal tidak memperhatikan lingkungan. Zaman dahulu orang Eropa ingin membangun kota yang ingin seperti kampung halamannya. Masalahnya, kanal menjadi tempat genangan yang menjadi sarang nyamuk. Selain itu dikuatkan oleh tulisan Kapten Cook tahun 1744, kota dibangun dengan bentuk bentengbenteng yang membuat sirkulasi udara buruk.

Gani juga menyebutkan epidemi yang muncul saat Culturstelsel (SistemTanam Paksa). Sistem Tanam Paksa mengakibatkan kemiskinan, yang kemudian menjadi penyebab kurangnya nutrisi, sandang yang buruk, dan hunian yang tak layak. Namun, epidemic yang muncul tahun 1845-1847 akhirnya menjadi pendorong dibangunnya Sekolah Dokter Djawa 1851. Ada satu hal yang menarik dituturkan oleh Gani bahwa wabah juga sedikit berkaitan dengan kebangkitan nasional, khususnya yang terjadi di Malang. Dokter Cipto mengkritik keras pemerintah kolonial saat itu yang tidak merespon wabah yang menjangkiti masyarakat pribumi. Kritiknya menyumbangkan motivasi untuk melakukan kebangkitan nasional. Selain itu, ia juga memaparkan pengaruh wabah beri-beri dalam Perang Aceh pada abad 19, penyakit pes yang muncul pada awal abad 20, dan penyakit cacingan yang menjadi awal penggalakan pembuatan toilet di Nusantara (Jaelani, 2020).

Menurut Oman, pandemic atau wabah bukan hal yang baru dalam kehidupan umat manusia. Pandemi-pandemi besar seperti wabah Yustinianus (plague of Justinian) pada 541-542 M, Maut Hitam (Black Death) pada 1347-1351 M, dan wabah Bombay (Bombay plague) pada 1896-1897 M telah terekam dalam memori umat manusia. Wabah seperti Flu Spanyol yang menyebar pada awal abad ke-20 menjadi pandemik terbesar yang banyak tercatat dalam sejarah Indonesia. Pandemi yang 
berulang kali terjadi di seluruh dunia telah mematahkan keilmuan dan riset di bidang medis, melahirkan interpretasi keagamaan yang menekankan keseimbangan iman dan akal, dan menghasilkan karya-karya yang menjadi inspirasi generasi kemudian dalam menyikapi pandemik wabah.

Para sarjana Muslim pada saat itu bergerak melawan wabah berdasarkan hadis Nabi Muhammad SAW yang menganjurkan masyarakat tidak boleh pergi ke daerah wabah, atau sebaliknya, jangan keluar dari wilayah wabah karena akan menularkan wabah ke wilayah lain. Dalam karya-karya terdahulu, misalnya karya Ibn al-Wardi, dijelaskan mengenai pengalaman kehilangan, cara penguburan, dan lain-lain. Menurutnya, tidak berdasar jika menganggap wabah ini adalah siksaan karena banyak ulama di masanya juga terdampak oleh wabah. Oman menuturkan bahwa dulu wabah mengikuti lalu lintas perdagangan dan pergerakan manusia. Sebagai contoh, haji di masa lalupun pernah dianggap menjadi kegiatan yang membahayakan karena dapat menyebarkan wabah kolera pada akhir abad 19 dan 20. Ritual ibadah haji bersifat kerumunan, sehingga saat itu dianggap menjadi salah satu penyebab penyebaran pandemic (Fathurrahman, 20 C.E.).

Dengan demikian nampak bahwa pandemi bisa menimbulkan gejolak sosial politik, seperti wabah Justinian, yang menyebabkan rencana Kaisar Justinia untuk menyatukan Kekaisaran Romawi gagal dan menyebabkan kekacauan ekonomi besarbesaran dan kejatuhan imperium Romawi. Wabah yang dikenal sebagai Black Death menyebabkan Inggris dan Prancis, yang saat itu berperang, untuk melakukan gencatan senjata. Hal ini juga dianggap menjadi awal dari keruntuhan sistem feodal Inggris karena berdampak pada demografi petani saat itu. Kekaisaran Aztec adalah korban dari wabah ini, ia runtuh pada tahun 1520 ketika banyak rakyatnya terinfeksi cacar oleh para budak Afrika. Pandemi kolera ini juga salah satu penyebab terjadinya revolusi Perancis (Paris) pada 1832. Pandemi juga merupakan salah satu penyebab keruntuhan VOC di Hindia Belanda pada abad 18 dengan mewabahnya penyakit malaria. Dokter Cipto yang dengan keras mengkritik pemerintah kolonial saat itu yang tidak merespon wabah malaria yang menjangkiti masyarakat pribumi, kritiknya itu menyumbang motivasi rakyat Indonesia untuk melakukan kebangkitan nasional.

\section{Kesimpulan}

Sejarah mencatat bahwa wabah penyakit disamping menimbulkan kematian, berpotensi menyebabkan kekacauan sosial politik bahkan sampai menumbangkan suatu rezim. Wabah juga bisa menyebabkan negara yang sedang berperang melakukan gencatan senjata seperti Inggris dan Prancis. Bahkan pandemi dianggap menjadi awal dari keruntuhan sistem feodal Inggris karena berdampak pada demografi petani saat 
Rusdi

Pandemi Penyakit Dalam Lintasan Sejarah dan Dampaknya Terhadap Gejolak Sosial Politik

itu. Di Indonesia, pada masa kolonial Belanda wabah malaria yang berkembang pada abad 18, selain merupakan salah satu penyebab runtuhnya VOC, juga menumbuhkan semangat kebangkitan nasional. Pandemi berakhir bisa disebabkan oleh seseorang yang terpapar wabah memiliki kekebalan tubuh seperti Wabah Justinian. Kemudian, ada juga pandemi berakhir dengan cara isolasi dan karantina. Cacar diberantas sebagai hasil dari penemuan vaksin. Ada pula virus yang menghilang secara misterius seperti flu Spanyol.

Kepanikan hingga langkah rasional kerap mewarnai tindakan manusia pada masa pandemi, kepanikan adalah proses yang wajar, itu dilakukan oleh manusia sepanjang masa sejarah pandemi. Namun, berusaha secara rasional, oleh umat manusia akan selalu selamat dari virus yang mengancam keberlangsungan hidup. Oleh karena itu, kelanjutan kajian mengenai sejarah penyakit semacam ini masih sangat diperlukan. Agar dapat digunakan sebagai bentuk peringatan, baik bagi pemerintah maupun masyarakat umum, tentang perlunya mencari sebanyak-banyaknya informasi dan referensi penanganan pandemi pada masa lalu.

\section{Daftar Pustaka}

Fathurrahman, O. (20 C.E.). Artikel Seminar Wabah dalam Lintasan Sejarah Umat Manusia. Museumnasional.or.Id2. https:// www.museumnasional.or.id/seminar-wabahdalam-lintasan-sejarah-umat-manusia-2-2709

Jaelani, G. A. (2020). Artikel Seminar Wabah dalam Lintasan Sejarah Umat Manusia. Museumnasional.or.Id; museumnasional.or.id.

https:// www.museumnasional.or.id/seminar-wabah-dalam-lintasan-sejarahumat-manusia-2-2709

Kahn, K. (2006). Dying to make a fresh start: mortality and health transition in a new South Africa. Folkhälsa och klinisk medicin.

Mardatila, A. (2020). Selain Corona, Ini 10 Pandemi Terburuk dalam Sejarah Dunia. Merdeka.Com.

Nursastri, S. A. (2020, April 20). Bagaimana 5 Pandemi Terburuk Dunia Berakhir? Sejarah Mencatat. Kompas.Com.

Ridho, M. (2020). Manusia VS Pandemi, dari Masa ke Masa. Asumsi.Co.Post.

Ridhoi, M. A. (2020). Sejarah Pandemi dan Epidemi di Dunia yang Memicu Gejolak Politik. Katadata.Co.Id.

Tahrus, Z. N. H. (2020). Unia dalam Ancaman Pandemi: Kajian Transisi Kesehatan dan Moralitas Akibat COVID-19 (Kajian Demografi Sosial, Departemen Sosiologi FISIP UI.).

Weeks, J, R. (2008). Population: An Introduction to concepts and issues Tenth Edition. Thomson Wadsworth. 